\title{
How It Came to Pass
}

I am not of sound mind. I cannot seem to stop moving-as I write this I have clocked 7,000 miles by truck in the last thirty days and I am hunkered in a motel room high in the Rocky Mountains and yet no nearer to God. I seek roots, just so long as they can accommodate themselves to around seventy-five miles an hour and no unseemly whining about rest stops or sit-down dinners. I am, I suspect, a basic American, a perpetual violation that loves the land and cannot kick the addiction of velocity. A person fated never to settle yet always seeking the place to settle. Like cocaine-powered athletes, lying presidents, Miss America, and the Internal Revenue Service, I am not a role model. And I am always hungry.

I can only make a stab at writing the truth if I tell others it is fiction-that way nobody gets too upset with me. I can only get started writing if I think it is music - that way I beat back my own cowardice.

I can only write if I don't think at all.

I have changed names and locations at times to protect the guilty. But everything happened as it is reported in this book, including the things scheduled for tomorrow or the day after that. 
THIS PAGE INTENTIONALLY LEFT BLANK 